\title{
The Impact Of Teacher Observations With Coordinated Professional Development On Student Performance: A 27-State Program Evaluation
}

Steven H. Shaha, Center for Policy \& Public Administration, USA Kelly F. Glassett, University of Utah, USA

Aimee Copas, North Dakota Council of Educational Leaders, USA

\begin{abstract}
The impact of teacher observations in alignment with professional development (PD) on teacher efficacy was quantified for 292 schools in 110 districts within 27 U.S. States. Teacher observations conducted by school leaders or designated internal coaches were coordinated with $P D$ offerings aligned with intended teacher improvements. The PD involved throughout was an online, on-demand system teachers accessed as convenient with a range of PD assistance regarding teaching techniques and participative teacher/user interactive communities for collaboratively posting and downloading PD-related materials. Results indicate that systemic teacher observations, coupled with aligned PD, resulted in significantly improved student achievement in reading and math on standardized assessments.
\end{abstract}

Keywords: Professional Development; Teacher Observation; Administrator Guidance; Student Performance

\section{INTRODUCTION}

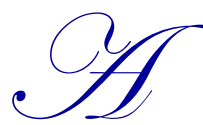

major purpose of schools and the school experience - arguably the major purpose - is to provide teacher-student settings and interactions that result in improved student capabilities and achievements. Schools and school districts struggle to identify ways to continuously improve the impact teachers have on their students (c.f. Duke \& Stiggins, 1990; U.S. Department of Education, 2013). Professional development and teacher observation are two example approaches school leaders invest in to ensure that teachers have a positive impact on student achievement.

Professional development (PD) remains a widespread approach aimed at improving teacher efficacy and impacts on students (Borko et al., 2006; Buczynski \& Hansen, 2010; Fishman et al., 2003; Loucks-Horsley et al., 2003; Mizell, 2010; Shaha et al., 2004).

Despite increased interest and expectations regarding PD, data substantiating improved impact of teachers on students remains sparse (Avalos, 2011; Desimone et al., 2002; Farnsworth et al., 2002; Garet et al., 2001; Lewis et al., 2003; Shaha et al., 2004). Such is especially the case for traditionally formatted PD approaches requiring teacher absences from classroom settings for participation and the expense and burdensome requirements to staff replacements.

The advent of Internet and expanding Internet video now provides PD for educators with fully convenient access and a more cost-effective approach to PD than traditional conference approaches requiring teacher absences from the classroom (Boling, 2007; Colestock \& Sherin, 2009; Sherin \& van Es, 2009). A growing number of recent rigorous studies have verified that teacher participation in Internet-based, online PD approaches is associated with favorable impacts on student performance (Buczynski \& Hansen, 2010; Desimone et al., 2002; Magidin et al., 2012; 
Masters et al., 2012; Rienties et al., 2013; Shaha \& Ellsworth, 2013, 2014; Wasik \& Hindman, 2011). Advanced Internet-based PD offerings specifically do not only include teacher-selected instructive videos and content, but also teacher communities within which PD participants can post and download PD-related materials from and for each other (c.f. Shaha \& Ellsworth, 2013, 2014).

In summary, findings from studies of online, on-demand, Internet-based PD have verified quantifiable, beneficial impacts on student performance. Arguably, online, on-demand PD provides a more cost-effective favorable approach than alternatives that require teacher absences and replacement. Thus, educators making decisions regarding investments in PD can now do so more enlightened based on research rather than based on teacher testimonials and marketing materials alone as was tradition.

Teacher Observations is another technique widely used wherein school leaders, experts, or designated coaches watch teachers and then provide feedback or guidance aimed at improving impact for classrooms and student learning. The school reform efforts of the 1980s and 1990s increased attention on observation-based teacher evaluations as a critical lever for improving the teaching quality and impact (c.f. Brandt, 1995; Darling-Hammond, 1990). Observation-based teacher assessments have continued to be predominately structured as once or twice yearly occasions on which administrators complete a checklist and ratings forms (Peterson, 2004; Weisberg, et al., 2009).

Teacher evaluation criteria has evolved over the past decades, as have beliefs and values surrounding the role of teachers, effective teaching, and theories of student learning (Cuban, 1993; Daley, \& Kim, 2010; DarlingHammond et al., 1983; Ellett, 1997; Ellett \& Teddlie, 2003). Observation-based assessment of teacher efficacy and quality have concurrently evolved from ethical perspectives reflecting teacher personal traits toward observable behaviors and practices (Ellett \& Teddlie, 2003; Good \& Mulryan, 1990).

Yet a review of the literature shows that typical teacher evaluations conducted by administrator observations have not proved consistently effective beyond meeting bureaucratic requirements (Darling-Hammond, 1986; Hazi \& Arredondo Rucinski, 2009; Jacob \& Lefgren, 2008; Peterson, 2000; Stiggins \& Bridgeford, 1985; Weisberg et al., 2009). Critiques include inadequate teacher training to remedy observed areas for improvement and weak proof that impacts of observations result in any level of higher student achievement (Darling-Hammond, 1986; Haefele, 1993; Jacob \& Lefgren, 2008; Medley \& Coker, 1987; Peterson, 2000). As a result, observations have suffered from mixed impacts or even minimal effectiveness.

In summary, teacher observations came with the goal that first-hand educator assessments would lead to identification of teacher strengths and weaknesses, followed by improved teacher capabilities and performance through improved teaching. Some studies have appropriately shown observations to be positive. However, to maximize effectiveness, it seems that observations and feedback to teachers should be focused on helping identify areas for their continuous improvement, resulting in increased impactfulness on students (Ellett \& Teddlie, 2003; Jacob \& Lefgren, 2008; Weisberg et al., 2009).

\section{SUMMARY}

What is needed is evidence that a coordinated use of improvement-focused teacher-observations with skillenhancing, readily accessible and adaptable PD can favorably impact teacher efficacy, as quantified in increases in student performance. What is missing is the tight alignment of observed needs with online PD offerings, the latter designed to help teachers improve, where needed, as measured in student improvements and achievement. The question is whether observation-based identification of teacher needs can lead to highly impactful PD improvements.

Studies continue to stress the ultimate goal of observations and PD focused on improved impacts (Gordon, Kane, \& Staiger, 2006; Rivkin et al., 2001; Rockoff, 2004; Rowan et al., 2002; Shaha et al., 2004; Wright, Horn, \& Sanders, 1997). To date, little quantitative evidence remains missing which shows that observation-based feedback can be combined effectively with PD to improve teacher skills and capabilities and their impact on student 
performance. Thus the purpose of the study described herein, which is long needed and will prove impactful for all educators focused on continuous teacher improvement for achieving improved student performance.

\section{METHOD}

Data analyzed included 292 schools in 110 districts within 27 states, representing an estimated 187,000 students within 54\% American states. School inclusion required a minimum of 15 teachers per school participating in the same commercially-available online, on-demand PD product widely used in the United States (PD $360 ®$ and Observation 360 ®, aka Edivation ${ }^{\circledR}$, School Improvement Network, Salt Lake City). This PD enabled teachers to participate in a full range of activities that ranged from instructional videos and content on specific teaching techniques and classroom challenges to user communities enabling posting, downloading and exchange of PDrelated materials.

Analyses of student performance across varying state locations and their respective assessments required a basis for collectively interpretable data. For this reason, status in student performance was quantified based upon the percentage of students classified as Proficient or Advanced in Math and Reading/Language Arts collectively by school. Within the 27 U.S. states included in the data, levels of student achievement were already categorized on scales within which students performing above minimum or average grade-defined levels were classified as either Proficient or Advanced in skill level, the second being the higher attainment. Using the sum of the percentage of students classified as either Proficient or Advanced provided the basis for collective analyses across settings and assessment instruments, as previously validated through published research. Data labelled as "Pre" reflected the 2010-2011 school year, while "Post" data were for the 2011-2012 school year.

Additional variables beyond student performance were collected reflecting levels of PD participation collectively by schools. Participation data were extracted from those automatically captured by the PD provider as an automated, automatic result of PD use. Data, summarized by school, reflected the following variables for analysis:

- $\quad$ Mean number of observations per teacher
- $\quad$ Average minutes viewed (i.e., PD video time)
- $\quad$ Forums viewed per teacher
- $\quad$ Files downloaded per teacher
- $\quad$ Files uploaded per teacher
- $\quad$ Links downloaded per teacher
-

Thus, the first data element - Mean number of observations per teacher - was captured as recorded within the PD application. This reflected the intentional connectivity between the numbers of observer-reported observation attempts as recorded within the online PD solution. The purpose of these observation events was, by instruction to observers, to determine teacher strengths and limitations and then to recommend the PD they subsequently should undertake for capability and impact enhancement purposes.

Schools (i.e., 292) were classified based upon the mean number of observations per teacher - ties were not an analytic challenge. Classifications were then labelled as Higher versus Lower Observation Rate groups (i.e., halves) which were created by dividing the schools into two equal groups of 146 each. The resulting mean number of teacher observations was 8.49 for the schools classified as Higher Observation Rate versus 2.76 for Lower Observation Rate schools.

Analyses followed a usual quasi-experimental design (Cook \& Campbell, 1979). All analyses were conducted using SPSS version 17.0 or higher (PASW Statistics, SPSS, 2009) and Excel (Microsoft Office 2007). Minimum level of statistical significance was determined a priori at $\mathrm{p}<0.05$. 


\section{RESULTS \& FINDINGS}

The data amassed reflected the combined effects of teacher observations and PD wherein the use of PD was often or always focused on observed areas of teacher need matched with appropriate PD usage.

\section{Math}

Schools with Higher Observation Rates experienced significantly greater gains in student performance for Math (see Table 1). Interestingly, and not by design, schools with the Higher Observation Rates had Pre-PD student performance levels 7\% lower than their Lower Observation Rates counterparts. However, the difference reversed or "flip-flopped" by the end of the PD year wherein the Higher Observation Rates schools shared an $11.5 \%$ advantage versus their Lower Observation Rates counterparts (see Figure 1).

Table 1: Comparative Student Gains (Math)

\begin{tabular}{lccccc}
\hline & \multicolumn{5}{c}{ Math Pct. Advanced + Proficient } \\
\hline & Pre & Post & Net Change & Pct. Change & p-Value \\
\cline { 2 - 6 } LOWER Observation Rates & 56.92 & 59.14 & 2.22 & $3.9 \%$ & $\mathrm{p}=0.016$ \\
HIGHER Observation Rates & 52.93 & 66.10 & 13.16 & $24.9 \%$ & $\mathrm{p}=<0.001$ \\
Significant Average & $\mathrm{p}<0.001$ & $\mathrm{p}<0.001$ & $\mathrm{p}<0.001$ & $\mathrm{p}<0.001$ & \\
\hline
\end{tabular}

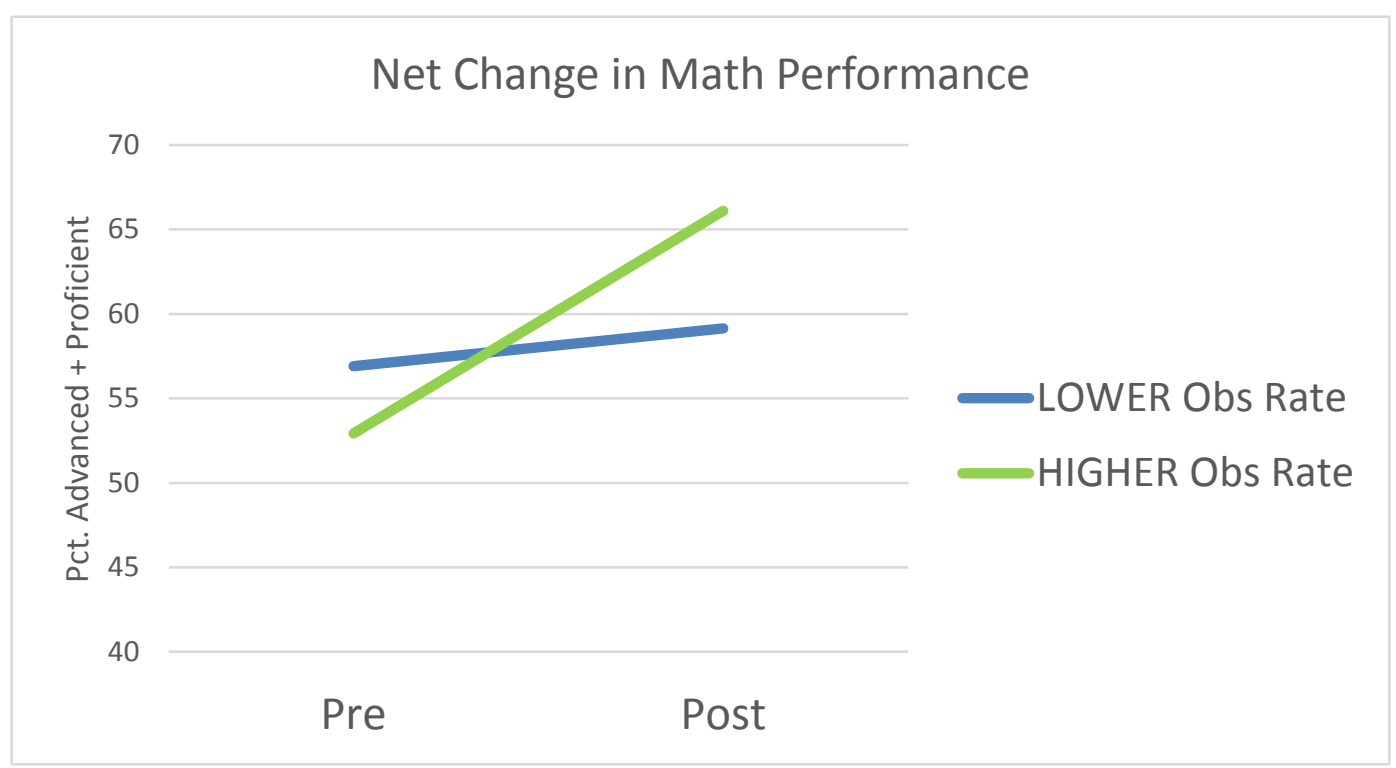

Figure 1: Comparative Improvement In Student Performance For Math

Schools with Lower Observation Rates collectively experienced 2.22 net gain in percent of students rated as Proficient or Advanced (see Table 1), which represented a statistically significant 3.9\% improvement ( $\mathrm{p}=0.016$ ). In contrast, schools with Higher Observation Rates collectively experienced 13.16 net gain in the percentage of students classified as Proficient or Advanced, representing a statistically significant $24.9 \%$ improvement from baseline $(\mathrm{p}<0.001)$. The comparison reflects 6.37 times the growth in the Higher Observation Rate schools compared with the Lower Observation counterparts.

As anticipated, teachers in Higher Observation Rates schools also experienced significantly higher utilization and engagement within the PD on several of the additional variables measured (see Table 2). This is interpreted as a reflection of the impact of the observations. Teachers in the Higher Observation Rates schools had $31.8 \%$ more observations with assignments, $39.5 \%$ more minutes of PD viewing, and 5.1\% more minutes of viewing per target (i.e., module). Thus, those more observed also used the PD more plentifully. 
Table 2: Comparative Teacher Engagement With Observation

\begin{tabular}{|l|c|c|c|}
\hline & Mean Obs w/Assignments & Ave. Minutes Viewed & Minutes Viewedper Target \\
\hline LOWER Observation Rates & 13.56 & 55.13 & 15.49 \\
\hline HIGHER Observation Rate & 17.87 & 76.88 & 16.28 \\
\hline Significant Average & $\mathrm{p}=0.048$ & $\mathrm{p}=0.032$ & $\mathrm{p}=0.050$ \\
\hline
\end{tabular}

\section{Reading}

Schools with Higher Observation Rates also experienced significantly greater gains in student performance in Reading (see Table 3). Again interestingly, and still not by design, schools with the Higher Observation Rates had Pre-student performance levels 12\% lower than their Lower Observation Rates counterparts. By the end of the PD year, the Higher Observation Rates schools nearly closed the massive pre-existing gap or disadvantage (see Figure 2).

Table 3: Comparative Student Gains (Reading)

\begin{tabular}{lccccc}
\hline & \multicolumn{5}{c}{ Reading Pct. Advanced + Proficient } \\
\hline & Pre & Post & Net Change & Pct. Change & p=Value \\
\cline { 2 - 6 } LOWER Observation Rates & 62.68 & 64.89 & 2.21 & $3.5 \%$ & $\mathrm{p}=0.016$ \\
HIGHER Observation Rates & 50.60 & 63.07 & 12.47 & $24.6 \%$ & $\mathrm{p}=0.001$ \\
Significant Average & $\mathrm{p}=0.001$ & $\mathrm{~ns}$ & $\mathrm{p}<0.001$ & $\mathrm{p}<0.001$ & \\
\hline
\end{tabular}

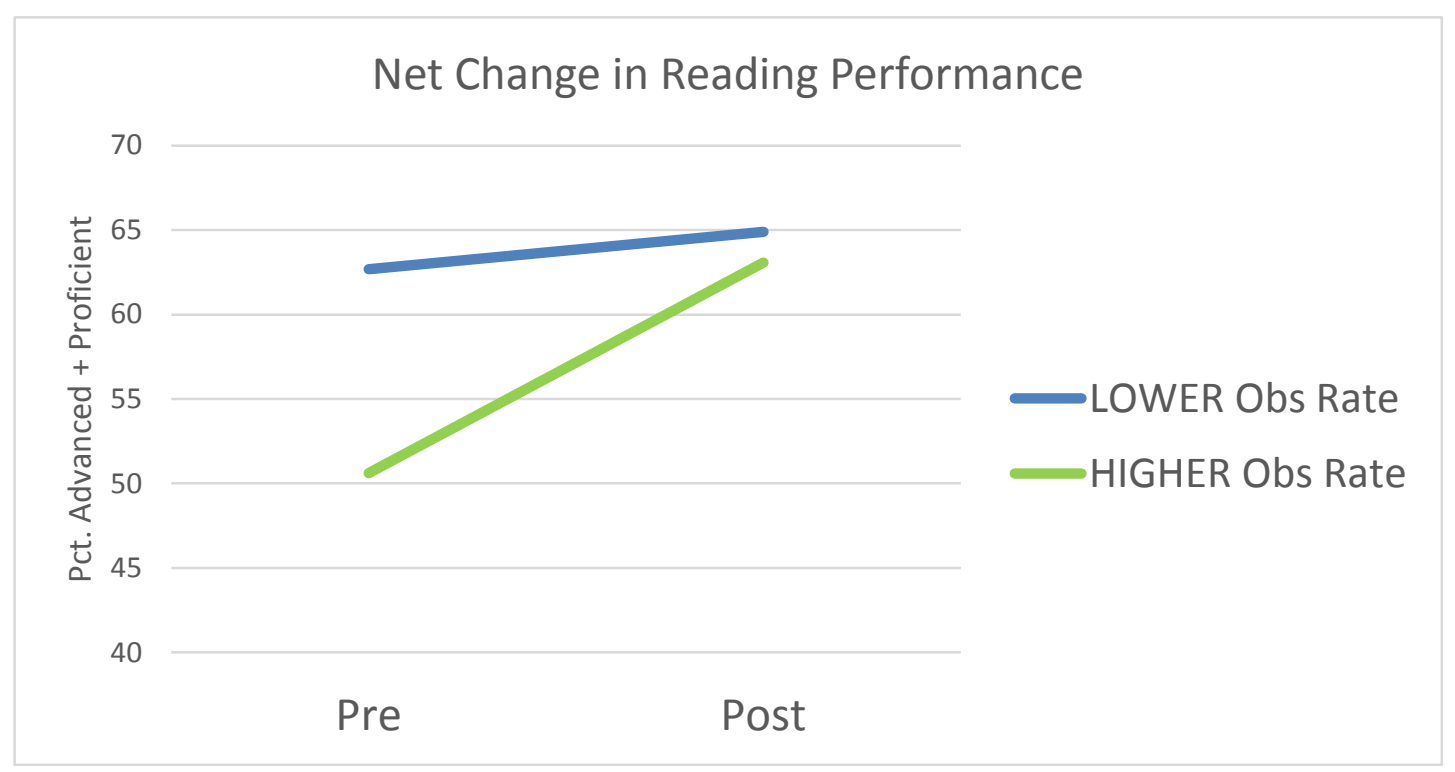

Figure 2: Comparative Improvement In Student Performance For Reading

Schools with Lower Observation Rates collectively experienced 2.21 net gain in the percent of students rated as Proficient or Advanced, which represented a statistically significant 3.5\% improvement $(\mathrm{p}=0.016)$. In contrast, schools with Higher Observation Rates collectively experienced 12.47 net gain in student performance for percent Proficient or Advanced, representing a statistically significant $24.6 \%$ improvement $(p<0.001)$ over baseline. The comparison reflects 7.01 times the growth in the Higher Observation Rate schools than was found for the Lower Observation counterparts.

Again as anticipated, data verified that teachers in Higher Observation Rates schools also used the PD at significantly higher rates of utilization and engagement within several of the additional variables measured (see Table 4). As with Math data, this is interpreted as a reflection of the impact of the observations as guidance and motivation to engage in the PD for improvement. Teachers in the Higher Observation Rates schools had more (3.2\%) observations with assignments, $29.9 \%$ more minutes of PD viewed, and 30.1\% more files downloaded. 
Table 4: Further Comparative Teacher Engagement With Observation

\begin{tabular}{|l|c|c|c|}
\hline & Percent Users w/ Viewing & Ave. Minutes Viewed & Files Downloaded \\
\hline LOWER Observation Rates & 0.79 & 62.17 & 24.42 \\
\hline HIGHER Observation Rates & 0.82 & 80.47 & 31.79 \\
\hline Significant & $\mathrm{p}=0.038$ & $\mathrm{p}=0.012$ & $\mathrm{p}=0.010$ \\
\hline
\end{tabular}

\section{CONCLUSIONS \& RECOMMENDATIONS}

Review of the literature revealed that efforts to maximize the impact of teachers on their students through teacher observations suffered generally from minimal effectiveness. Research proving the impact of professional development, however, has matured toward proof of impactfulness verified through significant improvement changes in student performance. The question remained as to the impact of the combination of the two approaches, with the anticipation that each and both would be more impactful together.

Data showed that students of teachers observed more frequently, as part of a coordinated undertaking and in conjunction with accessibility of an online, on-demand PD offering, collectively had greater gains in the performance of their students than those who had fewer observations. These same higher-observation teachers also proved to use the PD product more often and more actively, reflecting appropriate propensity among observers to recommend or direct specific PD undertakings in conjunction with specific observed areas for teacher improvement. The design of the study indicates that the combined PD-observation undertakings were mutually beneficial toward the teacher-on-student effects desired and sought.

This study indicates that use of a teacher observation system can reveal areas for improvement for which online, on-demand PD can provide coordinated remediation. This study further indicates, therefore, that the observational component of teacher evaluations should best be aligned with purposeful professional development. While teachers had open access to PD and were not limited to PD use only as directed by observers, it still remains compelling that teachers with more observations were also those with great PD use and whose students experienced greater collective improvements.

Whether the improvements in teacher efficacy in student performance were attributable to the observations or to the PD is indiscernible. Past studies in teacher observations lacked a connectivity with PD as a potentially enhancing coordination of effort and investment. Past studies have verified the impact of online, on-demand PD for student gains (c.f. Shaha \& Ellsworth, 2013, 2014), but teacher observations were not included in the design, so their coordinated impact is unknown. The combination of these research lackings makes this study more important and likely impactful but also sets a bar for next generation studies regarding programmatic approaches to improving teacher impacts on student performance.

These findings reflect massive numbers of teachers and students within enormous numbers of schools, districts and U.S. states, thus they have far-reaching implications for practice and policy. As policymakers work to improve the education in their schools and in those throughout America and the broader educational world, the central focus of validation and verification efforts must include the evaluation of teachers for the purpose of improving their impact on students. Although observation-based teacher evaluations might be criticized and disconnected from the needs of students, this study shows that a coordinated approach involving PD recommendations and executions is impactful for student advances. This study shows that a well-designed observation approach, combined with a proven online, on-demand PD, provides a rigorous, differentiated link for enabling teachers to have their greatest impact on students.

\section{AUTHOR INFORMATION}

Professor Steven Shaha, PhD, DBA, has conducted 100+ program evaluations in 35+ years on four continents in public, private, for-profit and not-for-profit sectors in various industries. Professor Shaha holds MA and MEd degrees, PhD in Research Methods \& Applied Statistics from UCLA, and DBA (PhD) in Business Administration from La Salle University. He has presented 200+ conference papers, has 100+ peer-reviewed publications, and two books. He is a full professor and has taught at 18 universities, e.g. Harvard, Cambridge (UK), Princeton, Columbia, 
Cornell, UCLA and Zayed University (UAE). He has helped non-educational organisations such as Disney, RitzCarlton, RAND Corporation, Time-Warner, Intel, IBM.

Kelly F. Glassett, $\mathrm{PhD}$, serves as content specialist for School Improvement Network. Previously he was an Associate Professor and Director of Teacher Education at Southern Illinois University, Carbondale with scholarship and research focus on teacher preparation, literacy and learning in $21^{\text {st }}$ century classrooms and technology integration in educational environments. He has worked as a classroom teacher in K-12 settings for 15+ years and taught at the collegiate level for 8+ years. He has authored or co-authored over 35 peer-reviewed articles and over 70 conference presentations on his research.

Aimee Copas, EdS, EdD, is the Executive Director for the North Dakota (ND) Council of Educational Leaders. Previously she served as Associate Vice Chancellor for Academic Affairs and the Director of Research for the North Dakota University System and as Academic Dean at Rasmussen College. She was also building principal, English teacher and head girls' basketball coach at Pollock School in Pollock, SD. Aimee has served on the ND State P-20 council, State Accreditation Advisory team, State ACT Board, and was the Higher Education lead for the Common Core State Standards implementation and consortia advisory group. Aimee received her MS at Northern State University, and both her Ed.S and Ed.D from the University of South Dakota.

\section{REFERENCES}

1. Avalos, B. (2011). Teacher professional development in teaching and teacher education over ten years. Teaching and Teacher Education, 27(1), 10-20. doi:10.1016/j.tate.2010.08.007.

2. Boling, E. C. (2007). Linking technology, learning, and stories: Implications from research on hypermedia video-cases. Teaching and Teacher Education, 23(2), 189-200.

3. Borko, H., Liston, D., \& Whitcomb, J. A. (2006). "A Conversation of Many Voices Critiques and Visions of Teacher Education." Journal of Teacher Education, 57(3): 199-204.

4. Brandt, R. M. (1995). Teacher evaluation for Career Ladder and Incentive Pay Programs. In D. L. Duke (Ed.), Teacher Evaluation Policy: From Accountability to Professional Development (pp. 13-34). Albany: State University of New York Press.

5. Buczynski, S., \& Hansen, C. B. (2010). Impact of professional development on teacher practice: Uncovering connections. Teaching and Teacher Education, 26(3), 599-607

6. Colestock, A., \& Sherin, M. G. (2009). Teachers' sense-making strategies while watching video of mathematics instruction. Journal of Technology and Teacher Education, 17(1), 7-29.

7. Cook, T. D., \& Campbell, D. T. (1979). Quasi-experimentation: Design \& analysis issues for field settings. Boston: Houghton Mifflin Company.

8. Cuban, L. (1993). How teachers taught: Constancy and change in American classrooms 1880- 1990 2nd edition. New York: Teachers College Press.

9. Daley, G., \& Kim, L. (2010). A teacher evaluation system that works. Natl Inst for Excellence in Teaching. Retrieved 8/20/14: http://www.tapsystem.org/publications/wp eval.pdf.

10. Darling-Hammond, L., Wise, A. E., Pease, S. R. (1983). Teacher evaluation in the organizational context: A review of the literature. Review of Educational Research, 53(3), 285-328.

11. Darling-Hammond, L. (1986). A proposal for evaluation in the teaching profession. The Elementary School Journal, 86(4), 530-551.

12. Darling-Hammond, L. (1990). Teacher evaluation in transition: Emerging roles and evolving methods. In J. Millman \& L. Darling-Hammond (Eds.) The new teacher handbook of teacher evaluation: Assessing elementary and secondary school teachers. Newbury Park: Sage.

13. Desimone, L. M., Porter, A. C., Garet, M. S., Yoon, K. S., \& Birman, B. F. (2002). Effects of professional development on teacher's instruction: Results from a three-year longitudinal study. Educational Evaluation and Policy Analysis, 24(2), 81-112.

14. Duke, D. \& Stiggins, R. J. (1990). Beyond minimum competence: Evaluation for professional development. In J. Millman \& L. Darling-Hammond (Eds.), The new handbook of teacher evaluation: Assessing elementary and secondary school teachers (pp. 116-132). Newbury Park: Sage.

15. Ellett, C. D. (1997). Classroom-based assessments of teaching and learning. In J. Stronge (Ed.) Evaluating teaching: A guide to current thinking and practice (pp. 107-128). Thousand Oaks: Corwin. 
16. Ellet, C. D. \& Teddlie, C. (2003). Teacher evaluation, teacher effectiveness, and school effectiveness: Perspectives from the USA. Journal of Personnel Evaluation in Education, 17(1), 101-128.

17. Farnsworth, B., Shaha, S., Bahr, D., Lewis, V., \& Benson, L. (2002). Preparing tomorrow's teachers to use technology: Learning and attitudinal impacts on elementary students. Journal of Instructional Psychology, 29(3).

18. Fishman, B. J., Marx, R. W., Best, S., \& Tal, R. T. (2003). Linking teacher and student learning to improve professional development in systemic reform. Teaching and teacher education, 19(6), 643-658.

19. Garet, M. S., Porter, A. C., Desimone, L., Birman, B. F., \& Yoon, K. S. (2001). What makes professional development effective? Results from a national sample of teachers. American Educational Research Journal, 38(4), 915.

20. Good, T. L., \& Mulryan, C. (1990). Teacher ratings: A call for teacher control and self-evaluation. In J. Millman \& L. Darling-Hammond (Eds.) The new teacher handbook of teacher evaluation: Assessing Elementary and Secondary School Teachers. Newbury Park: Sage.

21. Gordon, R., Kane, T. J., \& Staiger, D. O. (2006). Identifying effective teachers using performance on the job. Washington, D.C.: The Brookings Institution.

22. Haefele, D. L. (1993). Evaluating teachers: A call for change. Journal of Personnel Evaluation in Education, 7(1), 21-31.

23. Hazi, H. M., \& Arredondo Rucinski, D. (2009). Teacher evaluation as a policy target for improved learning: A fifty-state review of statute and regulatory action since NCLB. Education Policy Analysis Archives, 17(5). Online: http://epaa.asu.edu/epaa/v17n5/.

24. Jacob, B. A., \& Lefgren, L. (2008). Can principals identify effective teachers? Evidence on subject performance evaluation in education. Journal of Labor Economics, 26(1), 101-136.

25. Lewis, V. K., Shaha, S. H., Farnsworth, B., Benson, L., \& Bahr, D. (2003). The use of assessment in improving technology-based instruction programs. Journal of Instructional Psychology, 30(2).

26. Loucks-Horsley, S., Love, N. S., KE, M. S., \& Hewson, P. (2003). Designing professional development for teachers of science and mathematics $2^{\text {nd }} \mathrm{Ed}$.

27. Magidin, D. K., Masters, J., O'Dwyer, L. M., Dash, S., \& Russell, M. (2012). Relationship of online teacher professional development to seventh-grade teachers' and students' knowledge and practices in English language arts. The Teacher Educator, 47(3), 236-259. doi:10.1080/08878730.2012.685795.

28. Masters, J., Kramer, R. M. D., O’Dwyer, L., Dash, S., \& Russell, M. (2012). The effects of online teacher professional development on fourth grade students' knowledge and practices in English language arts. Journal of Technology and Teacher Education, 20(1), 21-46.

29. Medley, D. M., \& Coker, H. (1987). The accuracy of principals‘ judgments of teacher performance. Journal of Education Research, 80(4), 242-247.

30. Mizell, H. (2010). Why Professional Development Matters. Learning Forward (NJ).

31. Peterson, K. D. (2000). Teacher evaluation: A comprehensive guide to new directions and practices 2 nd edition. Thousand Oaks: Corwin Press.

32. Peterson, K. D. (2004). Research on school teacher evaluation. NASSP Bulletin, 88(639), 60-79.

33. Rienties, B., Brouwer, N., \& Lygo-Baker, S. (2013). The effects of online professional development on higher education teachers' beliefs and intentions towards learning facilitation and technology. Teaching and Teacher Education, 29(0), 122-131.

34. Rivkin, E. A., Hanushek, E. A., \& Kain, J. F. (2001). Teachers, schools, and academic achievement. Washington, D.C.: National Bureau of Economic Research.

35. Rockoff, J. E. (2004). The impact of individual teachers on student achievement: Evidence from panel data. The American Economic Review, 94(2), 247-252.

36. Rowan, B., Correnti, R., \& Miller, R. J. (2002). What large-scale survey research tells us about teacher effects on student achievement: Insights from the Prospects study of elementary schools. Teachers College Record, 104, 1525-1567.

37. Shaha, S. H., \& Ellsworth, H. (2013). Multi-State, Quasi-experimental Study of the Impact of On-demand Professional Development on Students Performance. International Journal of Evaluation and Research in Education (IJERE). Vol.2, No. 4.

38. Shaha, S. H., \& Ellsworth, H. (2014). Quasi-Experimental Study on the Impact of Online, On-Demand Professional Development on Educators in Title I Schools. Effective Education Journal. 
39. Shaha, S. H., Lewis, V. K., O'Donnell, T. J., \& Brown, D. H. (2004). Evaluating professional development: An approach in verifying program impact on teachers and students. Journal of Research in Professional Learning, 1(1), 1.

40. Sherin, M. G., \& van Es, E. A. (2009). Effects of video club participation on teachers' professional vision. Journal of Teacher Education, 60(1), 20-37.

41. Stiggins, R. J., \& Bridgeford, N. J. (1985). Performance assessment for teacher development. Educational Evaluation and Policy Analysis, 7(1), 85-97.

42. U.S. Department of Education, For Each and Every Child-A Strategy for Education Equity and Excellence, Washington, D.C., 2013.

43. Wasik, B. A., \& Hindman, A. H. (2011). Improving Vocabulary and Pre-Literacy Skills of at-Risk Preschoolers through Teacher Professional Development. Journal of Educational Psychology 103(2), 45569.

44. Weisberg, D., Sexton, S., Mulhern, J., \& Keeling, D. (2009). The widget effect: Our national failure to acknowledge and act on differences in teacher effectiveness. Brooklyn: The New Teacher Project. Available online at http://widgeteffect.org.

45. Wright, P., Horn, S. P., \& Sanders, W. L. (1997). Teacher and classroom context effects on student achievement: Implications for teacher evaluation. Journal of Personnel Evaluation in Education, 11(1): $57-67$. 
NOTES 